\title{
Development of the integrated assistance models to the child at institutional and inter-institutional level
}

\author{
O. Merfeldaitè, A. Railienè, V. Indrašienè, and V. Jegelevičienė \\ Mykolas Romeris University, Vilnius, Lithuania
}

\begin{abstract}
One of the aims of the Strategic Framework for European Cooperation in Education and Training (ET 2020) includes improvement of quality of education and training and equal opportunities for all, as well as development of social cohesion at all levels. The National Progress Programme for 2014-2020 highlights the necessity to enhance the inclusion of the disabled and other socially vulnerable groups in the education process. Thus, in response to the current challenges and changing public needs, and in order to create conditions for all children to gain education appropriate to their age and needs, school as the main child's socialisation institution shall ensure provision of high quality and comprehensive social pedagogical assistance. Only joint efforts of various specialists equipped with relevant knowledge/information and a wide range of abilities can ensure effective organisation and provision of social pedagogical assistance. One of the main conditions in providing social pedagogical assistance is teamwork providing for coordination of the activity of individual specialists, better identification of social assistance needs and development of inter-institutional and crosssection cooperation. The Article provides a draft model of integrated assistance to the child and a peer review. The analysis includes the ways of providing integrated assistance to the child, as well as changes to be made in the process of assistance to the child. The Article is concluded with the discussion where research results are summarised within the context of international research and practical experience.
\end{abstract}

\section{Introduction}

Social, political and economic conditions determine well-being of the society. New opportunities require new changes in the education system which plays a very important role in building an open civil society. The National Strategy on Education for 2013-2022 [1] highlights the necessity to create the conditions for each individual to engage in the learning process; in order to achieve this aim efforts have been taken to upgrade cooperation of relevant institutions. One of the aims of the Strategic Framework for European Cooperation in Education and Training (ET 2020) includes improvement of quality of education and training, equal opportunities for all, as well as development of social cohesion at all levels [2]. The National Progress Programme for 2014-2020 [3] highlights the necessity to enhance the inclusion of all socially vulnerable groups in the education process.

According to the researchers $[4,5]$, in response to the current challenges and changing public needs, and in order to provide the best possible conditions for all children to gain education appropriate to their age and needs, school as the main child's socialisation 
institution shall ensure the provision of high quality and comprehensive social pedagogical assistance.

Only joint efforts of various specialists equipped with relevant knowledge/information and a wide range of abilities can ensure effective organisation and provision of social pedagogical assistance.

One of the main conditions in providing social pedagogical assistance is team work providing for coordination of the activity of individual specialists, better identification of social assistance needs and development of inter-institutional and cross-section cooperation [6].

Provision of integrated social pedagogical assistance is endorsed in many national documents regulating education: the Law on Education of the Republic of Lithuania [7], the Description of the Procedure for Providing Social Pedagogical Assistance [8], the Law on Minimal and Average Assistance to the Child of the Republic of Lithuania [9], and other documents.

Lithuanian researchers provide an extensive analysis on the necessity of an individualised social pedagogical assistance in an educational institution in the context of problems faced by the child [4, 10-16]; activity of a social pedagogical assistance team, its efficiency and effectiveness [17-19]; social pedagogical assistance to the child in implementing the concept of minimal and average care to the child [20-24].

Foreign researchers also provide a broad-scale analysis for organisation of teamwork in providing counselling assistance to the child and youth experiencing academic and social problems in an education institution [25-32]; analyse functional modalities of specialists involved in this process [26, 33-36]; analyse specific nature of specialists' activity [37, 38] and the child's problem-solving process based on the teamwork [39-41]. The global education practice provides an extensive analysis of the activity of intervention assistance teams and a three-tiered intervention model in solving pupils' problems by involving children and their families in this process [42-52]. It should also be noted that the research is mainly directed toward the provision of psychological assistance and special education. Both, Lithuania and foreign countries still lack the research analysing an integrated assistance to the child in school at institutional and inter-institutional level.

The object of the research is provision of integrated assistance to the child, and the aim is to present a draft model of the process of integrated assistance to the child.

The following problematic issues have been identified in pursuing the above aim: how to organise effective provision of integrated assistance to the child? What changes are necessary in providing assistance to the child?

Research methods: secondary data analysis and expert survey.

Research methodology. Research was performed in September 2012-January 2013. It was organised in three stages. During the first stage, in order to develop the model of integrated assistance to the child, the analysis of secondary sources was carried out using the scientific books and journals, internet material and normative documents. Only the relevant information sources were selected, i.e. the sources ensuring reliability and validity of information. Based on the information of secondary sources, the second stage included development of the model of institutional and inter-institutional assistance to the child (hereinafter referred to as the assistance model to the child), which during the third stage was presented to experts; half-structured expert survey was also carried out. The expert method was aimed to analyse, evaluate and improve the prepared model for provision of assistance to the child.

The sample of the expert evaluation methodology involved 15 experts from Kaunas and Šiauliai cities and Joniškis district. The focus during the interviews was put on the main 
topic: the integrated approach and quality of assistance. In order to ensure holistic assessment of the presented model, three types of experts have been selected: representatives of school administrations (5 experts), experts representing assistance specialists (5), and class tutors (5). All experts had at least 10 years pedagogical work experience and were interested in the implementation of the above model in their institutions. Targeted selection principles were applied in selecting the respondents who could, taking account of the current situation in the institution, responsibly and critically identify advantages and disadvantages of the model.

The Article provides the summarised data of a qualitative interview content analysis and specifies strengths and weaknesses of the suggested model.

The research was executed according to the research-related ethical principles. During the research efforts have been taken to protect informants from moral, psychological or other harm. In order to maintain confidentiality, informants have been assigned a code number which guarantees anonymity (the first informant representing school administration: I-1; the one representing assistance specialists: II-1; class tutors' representative: III-1).

\section{Theoretical presentation of the model}

Development of the school network cooperation model was based on: social network development concept $[53,54]$, indicating importance of social networks for every participant of education; the concept of structure and dynamics of groups and organisation [55], highlighting the interaction and transaction as the main processes determining the purposefulness of the group activity and development of an organisation; systematic approach on the basis of which school as an organisation can grow and develop in interaction with the environment in interdependence and harmony [56]; the approach of anthropocentric philosophy highlighting that the learner is a free, rational and responsible personality, and that education creates favourable conditions for further self-education and learning.

Assistance to the child can be provided by the assistance specialists of one institution (school) if they have sufficient competence to pursue this activity. Otherwise, external social partners are invited to participate in the assistance process.

Levels of assistance organization. Assistance is provided according to an individual child assistance project; the responsibility for preparation and implementation of this project lies on the internal (institutional) and/or external (inter-institutional) network for child assistance.

The internal (institutional) assistance network includes specialists of one institution (school) aimed to provide children and their families with the necessary assistance in school if there is sufficient professional competence within that institution. According to the researchers [57] "teamwork can be facilitated by the awareness that you always have colleagues who are ready to help with their knowledge and support. Timely and adequate response of a social-pedagogical team to the problem, and provision of efficient assistance to pupils usually determine successful solution of problems."

The team of an internal (institutional) assistance network consists of: social pedagogue, class tutors, psychologist, special pedagogue, speech therapist, public health care specialist and representative of the administration. The team works according to the work regulation approved by the school leader and by the School Council (see Fig. 1). Assistance is provided individually to each pupil, i.e. according to an individual "assistance project".

According to A. Juodaityte [58], "reconstructions of individualised education can take place while observing, recording and distinguishing children's "messages", sent to adults from children's subculture, which have to be perceived by the educator as a discourse on individualised education and as metacontexts for pedagogical reconstructions." 


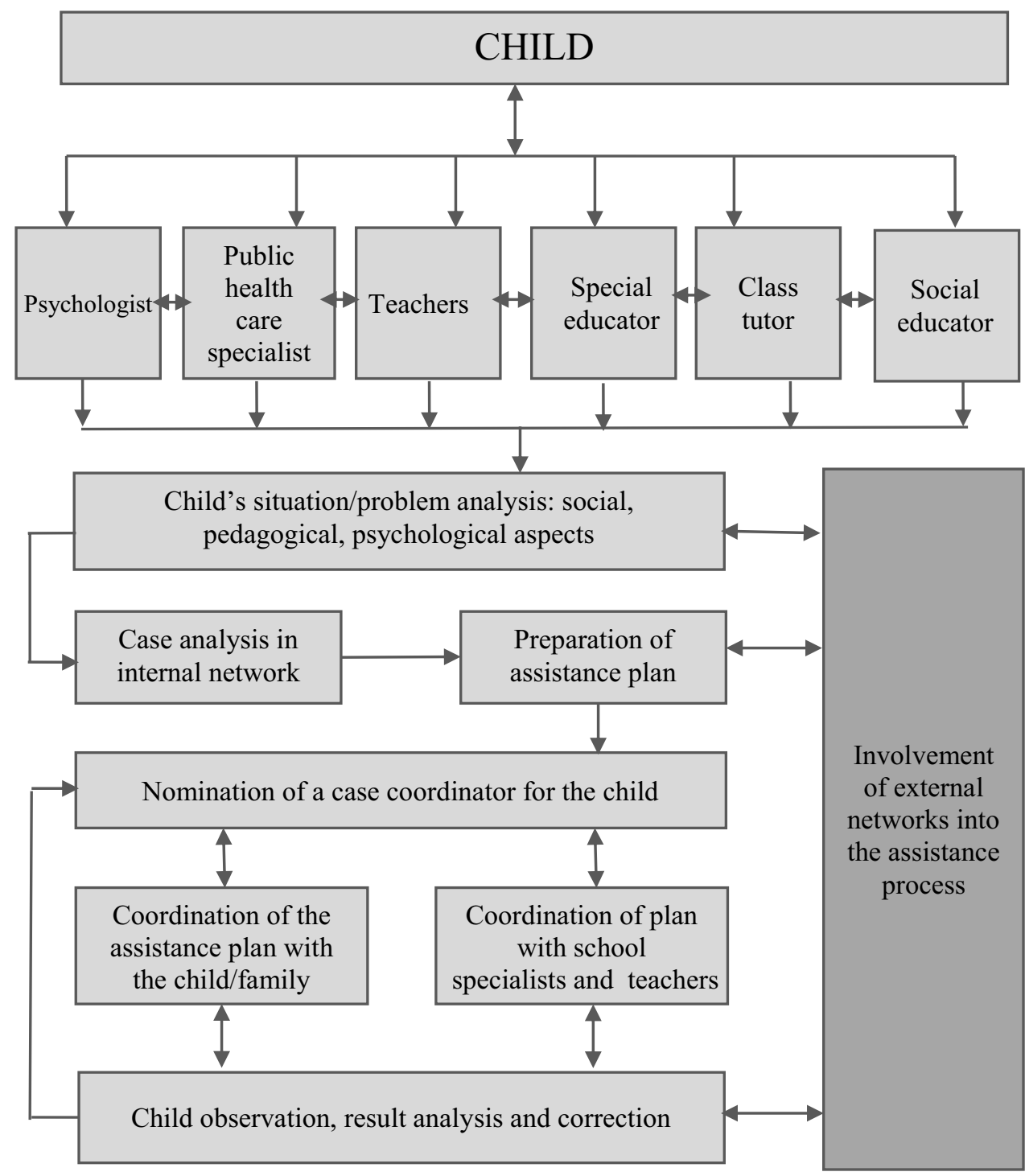

Figure 1. Model of internal (institutional) network.

The project for assistance to the pupil includes: pupil's case analysis, diagnostics of main problems and preparation of an individual assistance plan. It should be highlighted that the above plan is developed for the adaptive and post-adaptive periods. The plan shall include assistance goals and tasks; assistance activities; identification of possible assistance provision obstacles and measures for elimination of these obstacles; monitoring mechanism and evaluation of achievements and failures etc.

On the basis of possible problems, each child shall be provided with a case coordinator (assistance specialist) responsible for further process of child's adaptation and socialisation: observation of the child's behaviour, and initiation of the correction of the assistance plan. One more important detail of the assistance process is coordination of the assistance plan with the pupil, his/her parents and school teachers; the signed tripartite agreements shall indicate responsibilities of all the parties and responsibilities for a specific period. 
The external (inter-institutional) assistance network includes (besides the internal network) local (regional) social partners of schools working on a parity basis.

Importance of inter-institutional cooperation is reflected in the strategic national documents. Pursuant to Par.38 of the Order No A1-588 “On Action Plan for Increasing Social Inclusion 2014-2020" of 22 October 2013 of the Minister of Social Security and Labour of the Republic of Lithuania [59], it is envisaged to give more attention to the integrated approach and inter-institutional cooperation.

The institutions are involved following the nature of the emerging problems and the activity pursued by a specific institution. This determines the responsibilities of institutions delegated to them in solving the problems. The aim of external (inter-institutional) networks is to combine the professional skills, practical experience and knowledge of various specialists in coordinating specific actions aimed to ensure effective solution of children and families' problems which cannot be solved by individual specialists. The network of the external (interinstitutional) level supplements the team of an institutional level by one or several members of the following institutions: social worker of a local authority, representative of the Service for the Protection of Rights of the Child, officer for Juvenile Affairs in Police Department, representative of non-governmental organizations, representative of the Mental Health Centre and Pedagogical Psychological Service. Every member from the external level network takes part in this activity on parity basis. The external (inter-institutional) networks seek the goals ensuring the child's wellbeing: in-depth analysis of the child and their families' problems, joint planning of assistance actions and their implementation by connecting external network partner organizations; provision of and search for information to the institutional team; and implementation of the anticipated assistance measures for pupils. This process is also coordinated by a case coordinator (assistance specialist).

\section{Model evaluation}

Experts were asked to evaluate strengths and weaknesses of the child assistance model. It should be noted that all experts unanimously endorsed the necessity to initiate changes in the child assistance process and highlighted complexity, innovation and possibility to ensure assistance to the child at institutional and inter-institutional level: "an integrated approach was applied to child problems"(I-2); "it is very good that all assistance specialists, parents and administration are involved in the process (III-5); “ $<\ldots>$ complies with the integrated assistance provisions" (expert II-1).

Having evaluated strengths of the model indicated by all experts, three positive aspects of the model have been specified: better quality of assistance to the child, school communitybuilding and better involvement of parents and social partners.

The experts related the aspect of higher quality of assistance to the child to better understanding of children ("understanding diverse needs of children" (II-3); "Children's comprehensive understanding" (III-3); "Personal assistance to the child is based exceptionally on his/her needs" (I-4); "A specific child is identified, the efforts are made not to attribute children to certain groups $<\ldots>$ consequently, discrimination will decrease $<\ldots>$ risk groups etc." (II-5)); according to experts, this could be ensured only via open/friendly communication with the child (each child is given individual attention): "effective assistance is possible only when communication with the child is open and friendly" (III-3), " $<\ldots>$ possibility of personal contact at initial stages (it is not enough to ask "is everything okay?") $<\ldots>$ occasional problem-solving when problems have progressed far enough and you have to deal with their consequences" (I-4).

According to experts, in order to provide effective assistance it should be comprehensive, i.e. assistance should be provided not only directly to the child (by attracting all relevant 
assistance specialists, pedagogues and community), but, if needed, to the child's family: "Integrated assistance to pupils, family and the environment" (II-5); "Solution of specific complex (structural) problems" (I-4). It should be noted that today schools try to apply an integrated approach toward problem-solving; all specialists act within their respective competences, yet there is still lack of coordination of their activities, i.e. it is not clear who is responsible for coordination of each specific case. Therefore, explicit case coordination is so important in this process, i.e. the role of a case coordinator (this was highlighted by all experts (author's note): "case coordinator will take care of a specific child, look further at his/her problems and help to solve problems" (I-1), "usually class tutor is short of time and lacks relevant competences, therefore the role of a case coordinator is very important $\langle\ldots\rangle$ (III-2). (It should be noted that this model is attributed to the secondary assistance; responsibility for the primary assistance lies on the class tutor. It means that the model includes more complicated cases requiring an integrated approach to the problem).

An especially important aspect in the process of effective assistance is conclusion of a tripartite agreement between the family, child and case coordinator. "Agreements work well because all the parties make commitments" (II-2); $\langle\ldots\rangle$ it wouldn't be right to say that no actions are taken in schools, but problems usually arise when family requires help but doesn't take any actions itself" (III-4). It is noted that agreements are especially important in considering each individual case (child's problem). Experts emphasise the child's involvement in the self-help process as a positive aspect of the model, because the assistance plan is developed according to the child's needs and the child is responsible for realisation of this plan:

"Programme is directed toward the child"s desire to change" (II-4); "the child is involved in the project" (II-3). By helping themselves children can acquire new abilities (planning, social skills etc.): "The child gains positive experience" (I-3); "Formation of social skills of the child" (II-4); "Children become more open" (I-5); " $<\ldots>$ open/friendly relations with the child" (II-5); "Development of self-confidence and trust in others" (III-2).

It means that efforts are made to develop relations with pupils in the spirit of the equivalence principle and organise pupil-centred assistance: $\langle\ldots\rangle$ child is a personality, therefore it is necessary to communicate with him/her as to an equal person. Children's problems are important for us and we must take all efforts to help them solve these problems individually" (II-4).

Experts consider school community building as a supplementary measure in implementing the child assistance model, and provide several insights. The first is related to the communication and cooperation competence-building of all team members ensuring effective solution of problems: "Communication and cooperation of colleagues $<\ldots>$ so far they are reluctant to share information or consult with each other" (II-4); "interaction of persons with different competences" (II-3); "Personal and team competences are highlighted" (III-2); "Cooperation with others" $<\ldots>$ by the way, including school's cleaning and other auxiliary personnel“" (III-3); "Team-building is very important; it reduces resistance to various changes and provides for implementation of more innovations. Afterwards everybody will be able to work in a team and stop being selfish" (III-5). The second insight is related to the assumptions for formation of a new school culture: "Formation of cooperation culture in school" (I-1); "Microclimate and image of the school will improve" (I-3);" $<\ldots>$ changes in school (I-4). It can be said that the second insight of experts is a consequence of the first one.

Without any doubt, one of the model's strengths is improvement of the school-family relations and better involvement of social partners. Therefore, when evaluating the model the experts - class tutors - highlight that this creates a perfect opportunity for an actual (not imaginary) cooperation between the family and school: "Relations with family will 
improve" (III-2); $<\ldots>$ family will be directly involved in school's life for it is related to their children $\langle\ldots\rangle$ (III-4); "This opens up the possibility to work with families" (III-5).

Development of an inter-institutional partnership is emphasised by school administration leaders and assistance specialists: " $<\ldots>$ very often partnership is formal, and documents often 'settle" on the shelves $\langle\ldots\rangle$, of course, we understand that cooperation is necessary, but its purposes are not clear; here we deal with specific cases and responsibilities (I1); "Integrated assistance to pupils, families and environment"(I-2); $<\ldots>$ we do invite partners but often not the right ones $<\ldots>$; (II-2); "Relations with partners will increase" (II-4).

In realising the above model school teams related possible shortcomings to a possible negative school community's attitude, lack of pupils and parents' motivation and insufficient involvement of social partners.

Experts relate negative attitude of the school community to the reluctance of colleagues to cooperate and high time costs: "Colleagues don't want to cooperate, because everybody considers himself/herself as unique and special $\langle\ldots\rangle$ " (I-5); "Everybody wants to run home after work hours and is not inclined to share neither joys nor problems $<\ldots>$ (II-2); < .. > If staff is not paid it might be difficult to implement ideas for nobody is interested to spend even half hour for the additional work ,... >” (II-3); "Of course, assistance specialists cooperate with each other, but it is very difficult to attract teachers in this activity for they think that this is our (assistance specialists) responsibility (II-4); $<\ldots>$ this requires a lot of time, it is easier to make own decision, there is no need to waste time (III-1).

However, major doubts of experts are related to motivation of pupils and their parents, since success of assistance mainly depends on their willingness to accept help and on their active involvement and responsibility: "Children and families refuse to accept assistance" (I-4); "Children are reluctant to accept changes" (I-2); "Children themselves refuse assistance" $<\ldots>$ " (I-4); "Children don't want to analyse their behaviour" (III3); "Pupils lack responsibility"(II-2) "Parents are indifferent and lack commitment" (III1); "Indifferent attitude of parents, reluctance to participate"(III-2); "Insufficient parents" support to teachers and pupils" (III-5). $<\ldots>$ sceptical response of family $<\ldots>$ insufficient attention to the child's achievements" (III-1).

Problems related to the involvement of social partners are mainly determined by the lack of social partners' goodwill, insufficient competences and low motivation: "Problems occur when making contacts with partners: time; goodwill and competences of partners" (I-5); "Indifference of social partners" (II-1); "Insufficient number of external partners or their unwillingness to participate" (II-4).

In view of this, when implementing the above model it is necessary to strengthen school community, i.e. to organise additional training and prepare school community for implementation of the assistance model, clearly defining responsibilities of all members. When analysing involvement of the external partners it is necessary to emphasise mutual partnership which is possible only after discussing assistance goals and mutual benefits. One of the key recommendations is to increase parents ' motivation to participate in the process of assistance to the child.

\section{Discussion}

The model of integrated assistance to the child is directed to the child's needs/situation. Assistance is provided under a "single window" principle, i.e. each child has a case coordinator who helps the child to plan activities, discusses together his/her achievements 
and failures, and communicates with the child's family and school community. The importance of a person who is trusted by parents is highlighted by foreign researchers: parents are more apt to participate in the school's life and solve children's problems when they trust school's representative/pedagogue [60], and when they are invited (individually) to participate $[61,62]$. It means that the above model can help to identify the most important aspects of a successful activity with the children in difficulty including systemic assistance, belief in the child's success, and feedback to the child and his/her family.

In Lithuania this model could be applied in optimising activities of child welfare commissions at school and municipal levels. For that it is necessary to change the provisions of the Law on Minimal and Average Care of the Child by expanding the concept of the activity of child welfare commissions. The analysis of differences between this model and activities of the child welfare commissions in schools has evidenced several peculiarities. First of all this model highlights the assistance to the child (not disciplinary "measures" which could be treated as penalties); the assistance is provided by concluding assistance agreements with the child, pedagogues and child's parents; assistance is provided to each child, whereas minimal care to those who committed offenses/had behavioural problems/to pupils not attending school; besides, work of specialists is directed to the early prevention (not to consequences as is the case with the child welfare commissions). The minimal care implies work with the child for a certain period of time, whereas in this model the child himself/herself identifies changes, and efforts are made to allow the child experience the joy of success. It should be noted that assistance is provided to the close child's environment; all activities are coordinated with other specialists (this model falls out of the traditional school framework).

Compared to other global models related to the assistance to the child, according to the intervention philosophy this model complies with the philosophy of the Intervention Assistance Teams (IATs) applied in Europe and in the United States. The purpose of their activity is to help children solve the emerging emotional, behavioural, academic and other problems via active involvement of children and their families into the process [42] and an in-depth analysis of the current situation [63]. This model is also in line with the three-tiered Response to Intervention (RTI) model used in the United States. It is widely applied in the school practice and contributes to the achievement of positive results in the field of learning and behaviour [43-46]. The model developed in Lithuania complies with the second intervention tier of the RTI model. The above two models are similar in their organisational strategy and goals: the efforts are made to ensure favourable learning conditions for pupils, teachers and pupils' parents [47]. The model of integrated assistance to the child is in line with the main characteristics of the RTI model including: extensive pupil's analysis, provision of relevant data for problem identification, supervision of pupils' achievements, effective interventions and well-balanced teamwork [48-52, 64]. But one of the main characteristics of this model is that during the assistance process the child takes active part in the "self-help process", whereas in other models this element is absent. Therefore efforts are made to move gradually from the traditional impact paradigm to the interaction paradigm. Partner institutions are also being involved within the limits of their responsibility.

\section{Restrictions}

Pursuant to the research [50,65-67], in practice a seemingly simple application of this model (and RTI) requires major changes in the culture of school community and in the practical organisation of the educational process. "In order to change organisational culture 
of the entire organisation, first of all individual changes must take place"[68]. However, according to the research, these changes did not take place in Lithuania yet due to the still prevailing "negative attitude of parents, their indifference to children's problems, and lack of cooperation of other institutions in solving social - pedagogical problems of pupils" [57]. It means that realisation of the model will determine changes in the entire community.

\section{References}

[1] Valstybinė švietimo 2013-2022 metụ strategija, [interactive], <http://www . smm. It >

[2] $2012 \mathrm{~m}$. Tarybos ir Komisijos bendro pranešimo apie Europos bendradarbiavimo švietimo ir mokymo srityje strateginès programos ("ET 2020") igyvendinimą, projektas Švietimas ir mokymas pažangioje, tvarioje ir integracinejje Europoje. Briuselis, 2011.12.20 KOM (2011).

[3] 2014-2020 metụ nacionalinès pažangos programa, Lietuvos Respublikos Vyriausybès 2012 m. lapkričio 28 d. nutarimas Nr. 1482б [interactive], <http://www.smm. lt >.

[4] I. Leliūgienè, Socialinè pedagogika. Kaunas: Technologija (2002).

[5] G. Kvieskienè, Pozityvioji socializacija. Vilnius: Vilniaus pedagoginio universiteto leidykla (2005).

[6] O. Merfeldaitè, Socialinès pedagoginès pagalbos efektyvumas mokykloje: klasès auklètojų požiūris. Socialinis ugdymas. Vilnius, Nr. 3 (14), (2007).

[7] Lietuvos Respublikos švietimo istatymas. Valstybės Žinios, 1991, Nr. 23-593; 2003, Nr. 63-2853; 2004, Nr. 103-3755, Nr. 120-4437; 2006, Nr. 73-2758; 2007, Nr. 43-1628, Nr. 77-3045, Nr. 81-3324; 2009, Nr. 89-3802, Nr. 93-3975; 2010, Nr. 15-701.

[8] Socialinès pedagoginès pagalbos teikimo tvarkos aprašas. Valstybės žinios, 2011, Nr. 38-1804.

[9] Lietuvos Respublikos vaiko minimalios ir vidutinès priežiūros įstatymas (2007, 2010). Valstybės žinios, 2007. Nr. XI-1238; Valstybès žinios, 2010. Nr. XI-1232.

[10] L. Rupšienė, Nenoras mokytis - socialinis pedagoginis reiškinys. Klaipèda: Klaipèdos universitetas (2000).

[11] A.Ališauskas, Vaiko psichopedagoginis vertinimas: pokyčiu perspektyva: mokomoji knyga. Šiauliai: Šiauliụ universiteto leidykla (2007).

[12] O. Merfeldaite, Socialinès pedagoginès pagalbos komandos veiklos modelis bendrojo lavinimo mokykloje. Daktaro disertacija, Socialiniai mokslai, edukologija (07S) (2007).

[13] V. Indrašienè, V. Suboč, Tẻvụ požiūris i socialinès pedagoginès pagalbos mokykloje organizavimą. Socialinis ugdymas, 5(16) 59-72 (2008).

[14] V. Targamadzè, D. Valeckienè, E. Kvieskaitė, Mokykloje dirbančiụ specialistu brèžiamụ problemų eskizas pedagoginèje-psichologinèje erdvėje. Socialinis ugdymas, 5(16), 31-51 (2008).

[15] O. Merfeldaite, V. Indrašienè, Social Pedagogical Assistance in School as a means for Implementation of Social Justice in Education. Tiltai, 1(50). P. 63-71 (2010).

[16] V. Targamadzé, Tyrimas: "12-14 metụ mokiniụ mokymo(si) didaktinès problemos ir jụ sprendimo galimybės" (2009).

[17] O. Merfeldaitè, Socialinès pedagoginès pagalbos komanda ugdymo institucijoje: veiklos prielaidos ir organizavimo ypatumai. Pedagogika, 76, p. 51-55 (2005).

[18] O. Merfeldaitè, Socialiniu pedagoginiụ problemụ bendrojo lavinimo mokykloje analizè: mokiniụ ir klasiụ auklètojų požiūris. Pedagogika, 88, 43-49 (2007). 
[19] O. Merfeldaité, Tèvư ir mokyklos bendradarbiavimo stiprinimas sprendžiant vaikụ socializacijos problemas. Socialinis ugdymas, 8(19) 59-61 (2009).

[20] O. Merfeldaite, V. Indrašiené, Implementation of minimal care of children at the local self-government and institutional level. Socialinis darbas: mokslo darbai. Vilnius : Mykolo Romerio universitetas. 2011, 10(1), p. 6-11 (2011).

[21] O. Merfeldaité, J. Pivorienè. Vaikụ ir pagalbos specialistụ požiūris i socializacijos centruose teikiamą pagalbą vaikams. Socialinis darbas : mokslo darbai $=$ Social work : academic papers, Mykolo Romerio universitetas. Vilnius : Mykolo Romerio universitetas. 2011, 10(2), p. 255-266 (2011).

[22] V. Indrašienè, J. Pivorienè, Pagalba šeimai, kai vaikui paskirta vidutinès priežiūros priemonè. Socialinis darbas : patirtis ir metodai, Vytauto Didžiojo universitetas. Kaunas : VDU. 2012, 10(2), p. 65-82, 239-240 (2012).

[23] V. Indrašienè, O. Merfeldaite, Evaluation of the activity of the child welfare commission in pursuance of the minimal care of the child. SHS Web of Conferences: proceedings. 3rd international interdisciplinary scientific conference. Society. Health. Welfare. 1st Congress of Rehabilitation Doctors of Latvia. Vol. 2 / Rīga Stradiņš University. Les Ulis Cedex : EDP Sciences, 2012, p. 1-6 (2012).

[24] V. Indrašienė, O. Merfeldaitė, (2013). Social pedagogical assistance for children in socialization centres of Lithuania: aproach of those that render assistance. Nauki społeczne wobec kryzysu i nowych wyzwań. Teoria i praktyka / redakcja naukowa: Zdzisława Dacko-Pikiewicz, Ingrid Emmerovā. Toruń : Wydawnictwo Edukacyjne "AKAPIT", 2013, p. 323-334.

[25] B. Algozzine, J. Ysseldyke, The fundamentals of special education. Thousand Oaks, CA: Corwin (2006).

[26] J.E. Ysseldyke, M. Burns, S. Rosenfield,. "Blueprints" on the future of training and practice in school psychology: What do they say about educational and psychological consultation? Journal of Educational \& Psychological Consultation, 19, pp. 177-196 (2009).

[27] M. Snell, R. Janney, Teachers' problem-solving about children with moderate and severe disabilities in elementary classrooms. Exceptional Children, 66, pp. 472-490 (2000).

[28] P. Graczyk, C. Domitrovich, M. Small, J. Zins, Serving all children: Animplementation model framework. School Psychology Review, 35, 266-274 (2006).

[29] E. Robinson,. Involving the school psychologist. How to break the barriers to collaboration on professional development school leadership teams. Teacher Education and Practice, 12, 1-15 (1996).

[30] S. Rosenfield, T.A. Gravois, Instructional consultation teams: Collaborating for change. New York, NY: Guilford Press (1996).

[31] V. M. Young, D. H. Kim, Using assessments for instructional improvement: A literature review. Education Policy Analysis Archives, 18(19) (2010).

[32] M. Newell, The implementation of problem-solving consultation: An analysis of problem conceptualization in a multiracial context. Journal of Educational \& Psychological Consultation, 20, pp. 83-105 (2010).

[33] M. K. Burns, T. Symington, A meta-analysis of prereferral intervention teams: Student and systemic outcomes. Journal of School Psychology, 40, 437-447 (2002).

[34] K. P. Boudett, E. A. City, R. J. Murnane, (Eds.), Data wise: A step-by-step guide to using assessment results to improve teaching and learning. Cambridge, MA: Harvard University Press (2006). 
[35] J. L. Graden, Arguments for change to consultation, prevention, and intervention: Will school psychology achieve ever achieve this promise? Journal of Educational and Psychological Consultation, 15, 345-349 (2004).

[36] S. M. Donovan, C. T. Cross, Minority students in special and gifted education. Washington, DC: National Academy Press (2002).

[37] G.M. Crow, \& D.G. Pounder,. Interdisciplinary teacher teams: Context, design, and process. Educational Administration Quarterly, 36, 216-254 (2000).

[38] M.S. Twomey, G. Jackson, H. Li, T. Marino, L. Melchior, J.F. Randolph, T. RetselliDeits, J. Wysong, The Successes and Challenges of Seven Multidisciplinary Teams. Journal of Elder Abuse \& Neglect, 22:3-4, 291-305 (2010).

[39] T. J. D'Zurilla, A. M. Nezu, A. Maydeu-Olivares, Social problem solving: Theory and assessment. In E. C. Chang, T. J. D’Zurilla, \& L. J. Sanna (Eds.), Social problem solving: Theory, research and training (pp. 11-27). Washington, DC: American Psychological Association (2004).

[40] J. S. Newton, R. Horner, B. Algozzine, A. Todd, K. M. Algozzine, Using a problemsolving model for data-based decision making in schools. In W. Sailor, G. Dunlap, G. Sugai, \& R. Horner (Eds.). Handbook of positive behavior support (pp. 551-580). New York, NY: Springer (2009).

[41] P. Tysinger, J. Tysinger, T. Diamanduros. Teacher expectations on the directiveness continuum in consultation. Psychology in the Schools, 46, 319-332 (2009).

[42] V.M. Myers, Ch.E. Kline, Secondary School Intervention Assistance Teams: Can They Be Effective? The High School Journal, 85, Number 2, December 2001-January 2002 p. 33-42 (2002).

[43] L. Crawford, The Role of Assessment in a Response to Intervention Model, Preventing School. Failure: Alternative Education for Children and Youth, 58:4, 230-236 (2014).

[44] J. Wanzek, S. Vaughn, Research-based implications from extensive early reading interventions. School Psychology Review. 36(4):541-561 (2007).

[45] M. Burns, J.J. Appleton, J.D. Stehouwer, Meta-analytic review of responsivenessto-intervention research: Examining field-based and research-implemented models. Journal of Psychoeducational Assessment. 23:381-394 (2005).

[46] K. L. Lane, L. A. Rogers, R. J. Parks, J. L. Weisenbach, A. C. Mau, M. T. Merwin, W. A. Bergman, Function-based interventions for students who are nonresponsive to primary and secondary prevention efforts: Illustrations at the elementary and middle school levels. Journal of Emotional and Behavioral Disorders, 3, 169-184 (2007).

[47] G. Sugai, Responsiveness-to-intervention: Lessons learned and to be learned. Keynote presentation at and paper for the RTI Summit, U.S. Department of Education, Washington, DC (2007).

[48] R. Brown-Chidsey, M. W. Steege, Response to intervention: Principles and strategies for effective practice. New York: Guildford Press (2005).

[49] T. J. Christ, M. K. Burns, J. E. Ysseldyke, Conceptual confusion within response-tointervention vernacular: Clarifying meaningful differences. Communique, 34(3), 1-8 (2005).

[50] D. Fuchs, D. D. Deshler, What we need to know about responsiveness to intervention (and shouldn't be afraid to ask). Learning Disabilities Research \& Practice, 22, 129136 (2007).

[51] D. Fuchs, L. S. Fuchs, (Eds.). Responsiveness to intervention [Special issue]. Teaching Exceptional Children, 39(5) (2007).

[52] F. M. Gresham, D. J. Reschly, W. D. Tilly, J. Fletcher, M. Burns, D. Prasse, et al. A response to intervention perspective. The School Psychologist, 59(1), 26-33 (2005). 
[53] R.V. Wijk, F.A. Van Den Bosch, H.W. Volberda, Knowledge and networks. The Blackwell handbook of organizational learning and knowledge management. USA: Blackwell Publishing (2003).

[54] L. Darling-Hammond, M. McLaughlinas, Policies that support Professional Development in an Era of Reform. Phi Delta Kappan, 76(8) (1995).

[55] E. Berne, Ego states in psychotherapy. Intuition and ego states: The origins of transactional analysis (McCormick P. Ed.). San Francisco: TA Press (1977).

[56] M. Payne, Teamwork in multiprofessional care. USA: Palgrave (2000).

[57] D. Baraldsnes, A. Vaškienè, Socialinio pedagogo iššūkiai organizuojant ir teikiant socialinę-pedagoginę pagalbą mokiniams mokykloje. Tiltai. 1(62). P. 199-210 (2013).

[58] A. Juodaitytė, Vaikụ individualizuoto ugdymo pedagoginès rekonstrukcijos: diskursai ir metakontekstai .Tiltai. 1(66). P. 237-247 (2014).

[59] Lietuvos Respublikos socialinės apsaugos ir darbo ministro $2013 \mathrm{~m}$. spalio $22 \mathrm{~d}$. isakymu Nr. A1-588; patikslinta Lietuvos Respublikos socialinès apsaugos ir darbo ministro 2014 m. sausio 24 d. įsakymu Nr. A1-47 Socialinès įtraukties didinimo 2014$2020 \mathrm{~m}$. veiksmu planas.

[60] S. L. Christenson, The family-school partnership: An opportunity to promote the learning competence of all students. School Psychology Review, 33, 83-104 (2004).

[61] P. A. Halsey, Parent involvement in junior high schools: A failure to communicate. American Secondary Education, 34, 57-69 (2005).

[62] B. I. Shajith, W., P. Erchu, Bringing Parents to School: The Effect of Invitations from School, Teacher, and Child on Parental Involvement in Middle Schools. International Journal of School \& Educational Psychology, 2, 11-23 (2014).

[63] Intervention Assistance Teams. Arlington public schools. http://www.apsva.us/ page/1982

[64] H. H. Severson, H. M. Walker, J. Hope-Doolittle, T. R. Kratochwill, F. M. Gresham, Proactive, early screening to detect behaviorally at-risk students: Issues, approaches, emerging innovations, and professional practices. Journal of School Psychology, 45, 193-223 (2007)

[65] S. Fairbanks, G. Sugai, D. Guardino, M Lathrop, Response to intervention: Examining classroom behavior support in second grade. Exceptional Children, 73, 288-310 (2007).

[66] R. M. Gresham, Response to intervention: An alternative means of identifying students as emotionally disturbed. Education and Treatment of Children, 28, 328-344 (2005).

[67] T. Sandomierski, D. Kincaid, B. Algozzine, Response to intervention and positive behavior support: Brothers from different mothers or sisters with different misters? Positive Behavioral Interventions and Supports Newsletter, 4(2), 1-4 (2007).

[68] I. Stravinskienè, M. Misiūnas, Kaita ir keitimasis - efektyvios kokybès vadybos sistemos pagrindas. The Quality of Higher Education, 7, p. 132-154 (2010). 